\title{
Application and reliability of techniques for landslide site investigation, monitoring and early warning - outcomes from a questionnaire study
}

\author{
I. Baroñ ${ }^{1, *}$ and R. Supper ${ }^{1}$ \\ ${ }^{1}$ Geological Survey of Austria, Neulinggasse 38, 1030 Vienna, Austria \\ * present address: Working Group on Karst and Caves, Department of Geology and Paleontology, Museum of Natural History, \\ Museumsplatz 1/10, 1070 Vienna, Austria \\ Correspondence to: I. Baroň (ivobaron@ centrum.cz)
}

Received: 21 December 2012 - Published in Nat. Hazards Earth Syst. Sci. Discuss.: Revised: 10 July 2013 - Accepted: 12 September 2013 - Published: 9 December 2013

\begin{abstract}
The presented questionnaire study summarizes an evaluation of approaches, techniques and parameters of slope-instability investigation and monitoring of their occurrence, reliability and the applicability of the monitoring techniques for early warning. The study is based on information collected from 86 monitored landslides in 14 European and Asian countries. Based on the responses, lidar ALS (airborne laser scanners), geophysical logging, aerial photographs, resistivity surveying, GB InSAR (ground-based synthetic aperture radar interferometer) and the refraction seismic were considered the most reliable methods for investigation of structure and character of landslides. Especially lidar ALS and geophysical logging were ranked high despite their application at relatively few landslides. Precipitation amount, pore-water pressure and displacement monitored by wire extensometers, dGPS and total stations, followed by air temperature and EM-emissions monitoring and displacement monitored by the TM 71 crack gauge were considered the most promising parameters for early warning.
\end{abstract}

\section{Introduction}

Mass movements are one of the worst natural threats worldwide. Consistent information about individual unstable slopes, especially in very vulnerable areas, on their internal structure, dynamics of deformation, triggers, history and possible magnitude is an essential input for any proper evaluation in advance of the actual hazard and for early warning before a catastrophic event.

Such knowledge is obtainable only through a complex interdisciplinary approach consisting of investigations by variety of methods and techniques, long-time monitoring of deformation and triggering factors, and by establishing early warning centres.

Several studies attempted to review and to list the techniques applied for landslide investigation, monitoring and early warning (Angeli et al., 2000; Jaboyedoff, 2012; Jongmans and Garambois, 2007; Michoud et al., 2012, 2013; Thiebes, 2012; Turner and Schuster, 1996). As different techniques and sensors of landslide investigation, monitoring and early warning provide a different kind of information with different data reliability, we tried to provide a quantitative comparison of those methods. The evaluation was based on a questionnaire study; the "Questionnaire on National State of Landslide Site Investigation and Monitoring" had been distributed worldwide to different institutes through our cooperating partners within the frame of the SafeLand project. The forms were completed by local experts responsible for the respective sites; thus the results reflect the practical experience from the field. The main goals of the study were (i) reviewing the general state of slope-instability investigation and monitoring approaches in different European and Asian countries, (ii) assessing effectiveness/reliability of each method for slope instability investigation and monitoring, and (iii) evaluating applicability of the monitoring techniques for early warning. The study complements similar research presented 

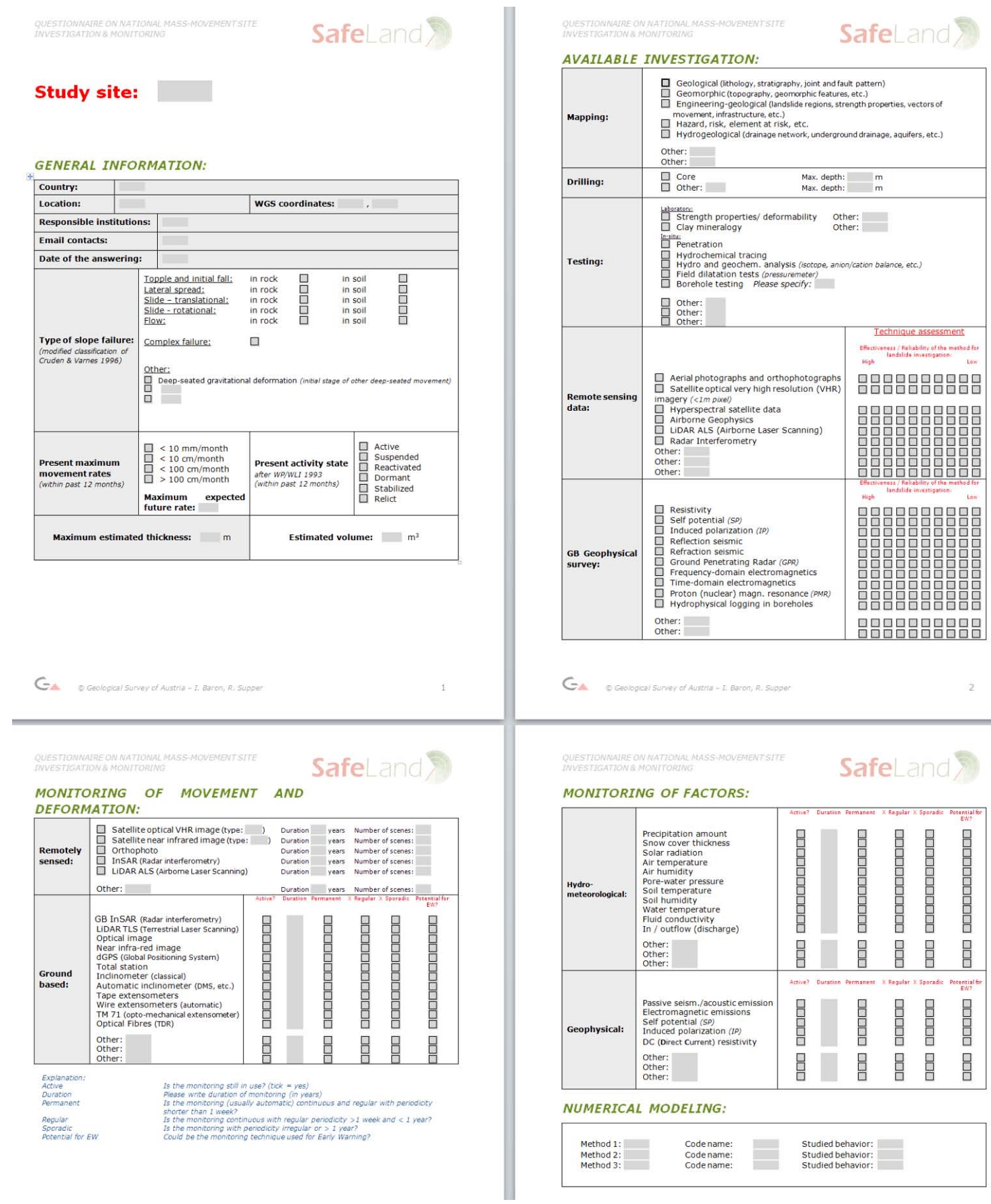

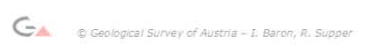
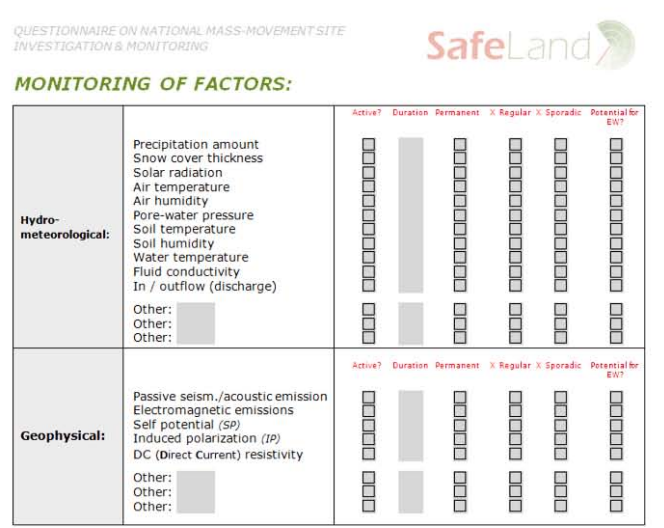

NUMERICAL MODELING:

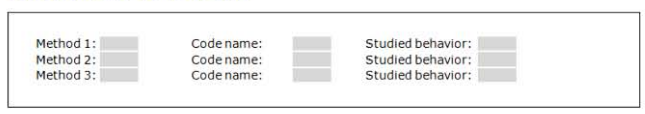

Fig. 1. General appearance of the "Questionnaire on National State of Landslide Site Investigation and Monitoring."

by Tofani et al. (2013), which is focused specifically on remote-sensing approaches for landslide monitoring, and by Michoud et al. (2013), focused on the operating landslide early-warning centres.

\section{Methods - the questionnaire and data evaluation}

The questionnaire focused on landslides that have been investigated with at least two independent methods and monitored for longer than $1 \mathrm{yr}$. A Word-doc application was prepared in a comprehensive and user-friendly way (Fig. 1). Answers were provided by ticking and filling in the active fields of the form. 


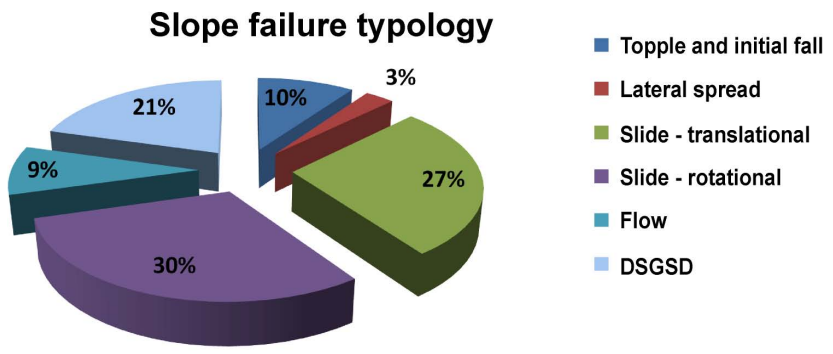

Fig. 2. Review of the total 129 monitored slope failure types from 86 sites that were included in the study. Note that $31 \%$ of them formed complex failures (modified classification of Cruden and Varnes, 1996).
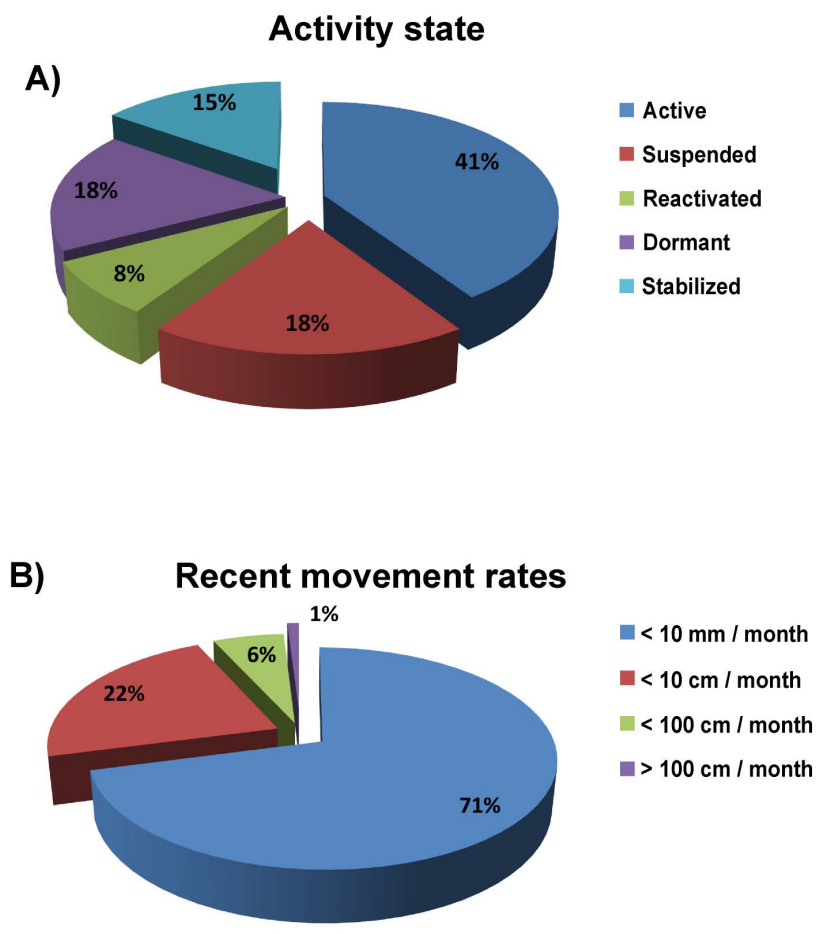

Fig. 3. Review of slope failures included in the study by (A) activity state (after WP/WLI, 1993) and (B) actual movement rates at time of response.

The general information on monitored mass movement consisted of information such as slope failure typology, activity state and recent movement rates. The classification was adopted and modified from Cruden and Varnes (1996). Different types of mass movements were then expressed relative to the total number of the particular landslide types within monitored sites, the complex failures excluded and expressed relative to the number of monitored sites.

The investigation methods, monitored parameters, and, in case of displacement, the individual monitoring techniques, were characterized by their (i) total relative occurrence [\%], i.e. the method occurrence related to the total number of

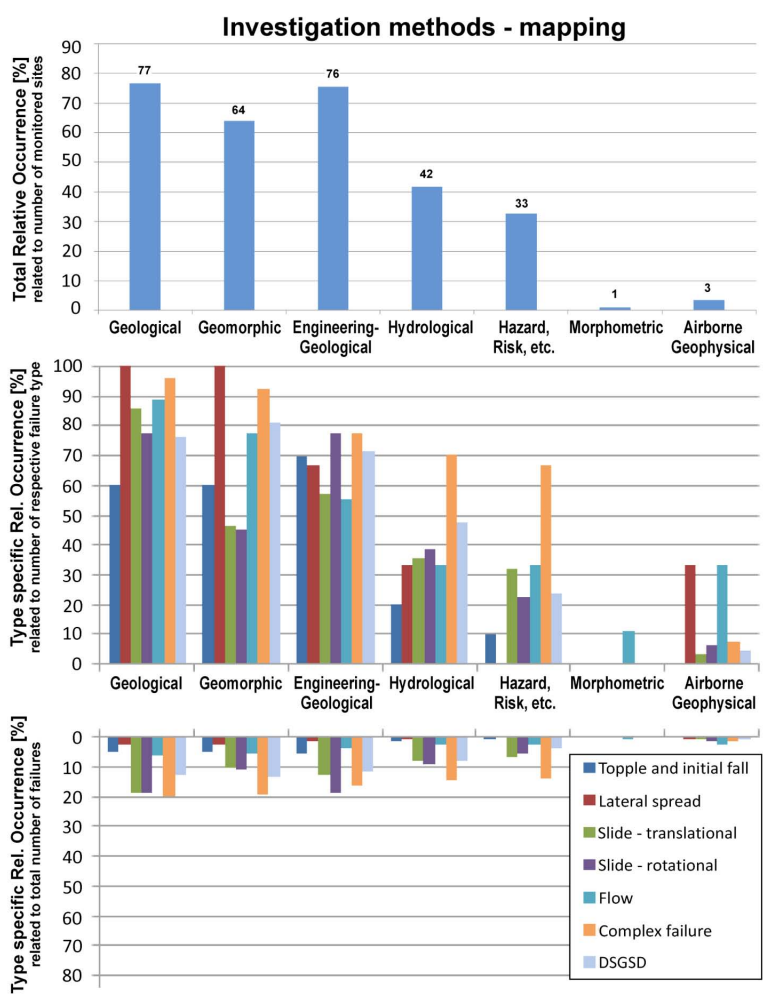

Fig. 4. Review of total relative occurrence and type-specific relative occurrence of the mapping approaches applied in the monitored landslide sites.

monitored sites included in the study, (ii) type-specific occurrence [\%] of each method at different types of slope failures related to the number of respective failure type, and (iii) type-specific occurrence of each technique at different types of slope failures related to the total number of all monitored landslide types (including partial slope-failure types forming complex landslide sites). Individual techniques were then scored from 1 to $10(1-100 \%)$ regarding their reliability [\%], i.e. the effectiveness of each method for slope-instability investigation and monitoring estimated subjectively by the respondents according to their practical experience. And finally, the applicability (or future potential) of the monitoring methods for early warning (i.e.; is the method suitable for early-warning purposes?) - called the early warning potential [\%] - was evaluated subjectively by the respondents answering "yes" or "no"; positive answers have been averaged with respect to the abundance of the technique (i.e. total number of each particular method applied in all monitored sites) and normalized by the technique of total relative occurrence. 
Investigation methods - drilling \& trenching
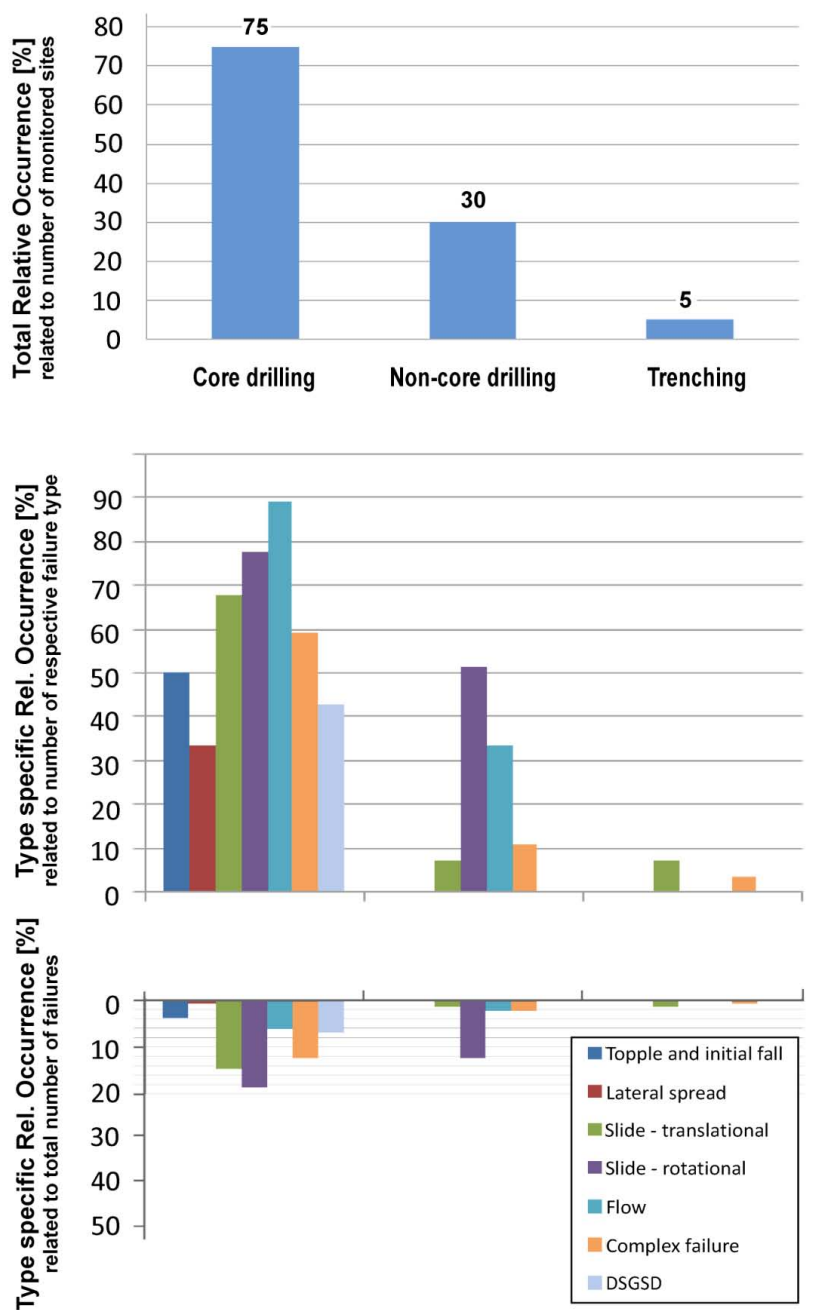

Fig. 5. Review of total relative occurrence and type-specific relative occurrence of drilling and trenching approaches applied in the monitored landslide sites.

\section{Results}

\subsection{Review of monitored sites to be evaluated}

The information has been collected from 86 monitored sites from Andorra, Austria, Switzerland, the Czech Republic, France, Great Britain, Italy, Japan, Kyrgyzstan, Norway, the Russian Federation, Slovenia, the Slovak Republic and Spain (Table 1), which included a total of 129 different slopefailure types. The most abundant slope failures that have been monitored were rotational slides $(30 \%)$, translational slides $(27 \%)$, and deep-seated gravitational slope deformations (DSGSD) with a total relative occurrence of $21 \%$ (Fig. 2). Topples and initial falls (10\%), flows (9\%) and lateral spreads $(3 \%)$ were much less abundant in the respondedto monitored sites. About $31 \%$ of those particular landslide
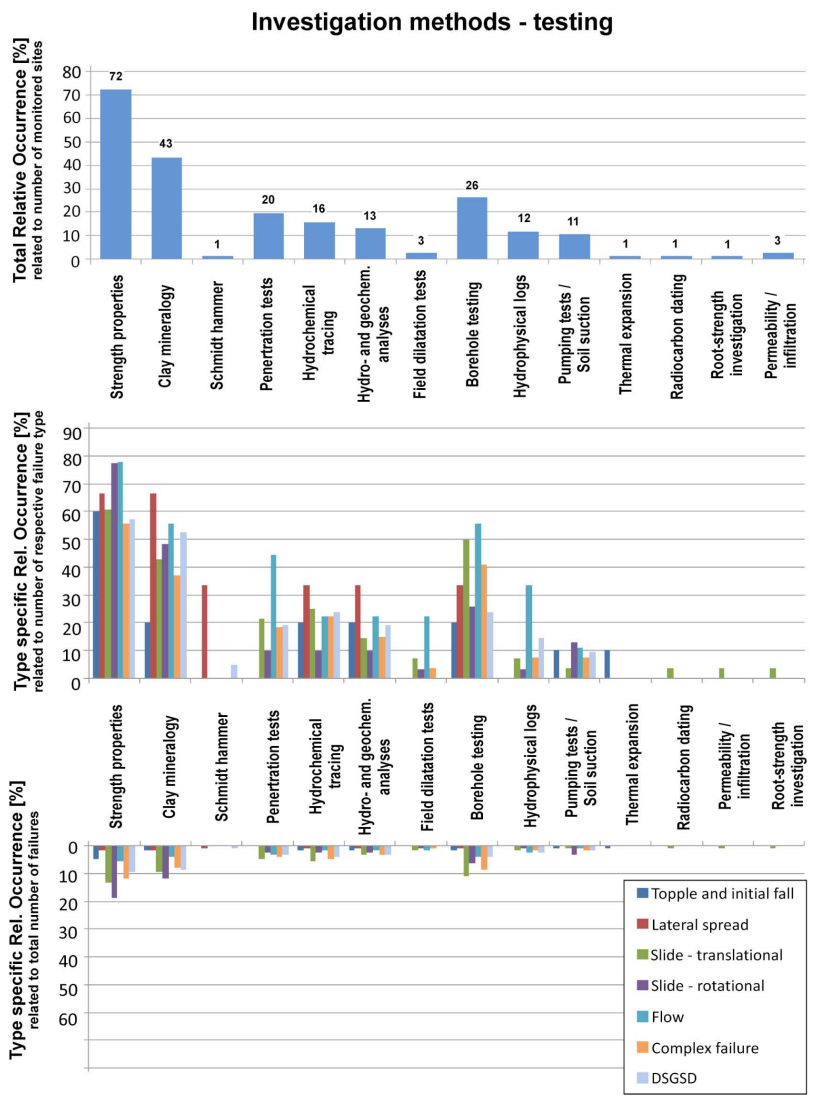

Fig. 6. Review of total relative occurrence and type-specific relative occurrence of testing approaches applied in the monitored landslide sites.

types formed complex failures. Regarding their activity state, the most abundant slope failures were the active ones $(41 \%)$ with recent movement rates of less than $10 \mathrm{~mm} m o n t h^{-1}$ (71\%) (Figs. 2, 3).

\subsection{Review of the investigation methods}

The most common mapping approaches applied at the monitored sites were the geological mapping (applied at $77 \%$ of the sites), engineering-geological (76\% of the sites) and geomorphic (64\% of the sites) (Fig. 4). Their application, however, differed at particular landslide types; for more details see type-specific relative occurrence in Fig. 4. Core drilling had been applied at $75 \%$ of the sites, mostly at rotational and translational slides (Fig. 5).

Strength properties/deformability (at $72 \%$ of the sites), clay mineralogy testing $(43 \%)$ and borehole testing $(26 \%)$ represented the most abundant testing surveys of the monitored sites (Fig. 6). For their application at particular landslide types see their type-specific relative occurrence in Fig. 6.

DC (direct current) resistivity (applied at $62 \%$ of the sites) and refraction seismic surveying (41\%) were the most 
Table 1. Review of responses: countries, monitored sites and authors.

\begin{tabular}{|c|c|c|c|c|c|c|c|}
\hline No. & Country & Site & Author & No. & Country & Site & Author \\
\hline 1 & Andorra & Canillo & J. Corominas & 44 & Italy & Tessina & A. Passuto \\
\hline 2 & Austria & Kerschbaumsiedlung & gbl.minntal@die-wildbach.at & 45 & Italy & Magliatica & G. Truffelli \\
\hline 3 & Austria & Blaubach & V. Kaufmann & 46 & Italy & Bosmato-Stadelte & M. Broccolato, J. Blanc \\
\hline 4 & Austria & Murenbach & Ch. Ihrenberger & 47 & Italy & Vollein & M. Broccolato, J. Blanc \\
\hline 5 & Austria & Sibratsgfäl/Rindberg & M. Wöhrer-Alge & 48 & Italy & Letze-Bosmato & M. Broccolato, J. Blanc \\
\hline 6 & Austria & Gschliefgraben & W. Gasperl & 49 & Italy & Becca di Nona & M. Broccolato, J. Blanc \\
\hline 7 & Austria & Maesstobel & WLW & 50 & Italy & Pitigliano & N. Casagli \\
\hline 8 & Austria & Wagrainer Ache & WLW & 51 & Italy & San Miniato & N. Casagli \\
\hline 9 & Switzerland & Gruben & S. Springman & 52 & Kyrgyzstan & Gulcha-Basar & I. Torgoev \\
\hline 10 & Switzerland & Ruedlingen & S. Springman & 53 & Kyrgyzstan & Kambar-Ata & I. Torgoev \\
\hline 11 & Switzerland & Tössegg & S. Springman & 54 & Kyrgyzstan & Kok-Jangak, Kapitalnja & I. Torgoev \\
\hline 12 & Czech Rep. & Pustevny & J. Klimes & 55 & Kyrgyzstan & Min-Kush & I. Torgoev \\
\hline 13 & Czech Rep. & Halenkovice & M. Bil & 56 & Kyrgyzstan & M-Suu Izolit & I. Torgoev \\
\hline 14 & Czech Rep. & Holstejn & V. Hanzl & 57 & Kyrgyzstan & M-Suu Tektonik & I. Torgoev \\
\hline 15 & Czech Rep. & Příhrazy & J. Rybar, J. Klimes & 58 & Kyrgyzstan & M-Suu, Koy-Tash & I. Torgoev \\
\hline 16 & Czech Rep. & Třebenice & J. Rybar, J. Klimes & 59 & Kyrgyzstan & Taran-Basar & I. Torgoev \\
\hline 17 & Czech Rep. & Čeřeniště & J. Rybar, J. Klimes & 60 & Norway & Aaknes & L. H. Blikra \\
\hline 18 & Czech Rep. & Ondřejník & J. Rybar, J. Klimes & 61 & Norway & Jettan & L. H. Blikra \\
\hline 19 & Czech Rep. & Karolinka & P. Blaha & 62 & Norway & Mannen & L. H. Blikra \\
\hline 20 & Czech Rep. & Ujala & P. Blaha & 63 & Russia & Zagorsk & M. M. Ilyin \\
\hline 21 & Czech Rep. & Obri Hrad & F. Hartvich & 64 & Slovenia & Macesnik & M. Carman, S. Kumelj \\
\hline 22 & Czech Rep. & Pravcicka brana & Z. Varilova & 65 & Slovenia & Slano Blato & M. Carman, S. Kumelj \\
\hline 23 & Spain & Vallcebre & J. Corominas & 66 & Slovenia & Stože & M. Carman, S. Kumelj \\
\hline 24 & France & Mas d'Avignonet & D. Jongmans & 67 & Slovakia & Banska Stiavnica & P. Wagner \\
\hline 25 & France & Super Sauze & J.-P. Malet & 68 & Slovakia & SK Bojnice & P. Wagner \\
\hline 26 & France & Villerville & J.-P. Malet & 69 & Slovakia & Demjata & P. Wagner \\
\hline 27 & France & La Valette & J.-P. Malet & 70 & Slovakia & Dolna Micina & P. Wagner \\
\hline 28 & France & Séchilienne & S. Garambois, A. Helmstetter & 71 & Slovakia & Fintice & P. Wagner \\
\hline 29 & Great Britain & Hollin Hill & C. Foster & 72 & Slovakia & Handlova 1960 & P. Wagner \\
\hline 30 & Italy & Cervinara & L. Picarelli & 73 & Slovakia & Handlova - Kunesov road & P. Wagner \\
\hline 31 & Italy & Castagnola & N. Casagli & 74 & Slovakia & Hlohovec & P. Wagner \\
\hline 32 & Italy & Masseria Marino & G. Urciuoli & 75 & Slovakia & K Klecenov & P. Wagner \\
\hline 33 & Italy & Santo Stefano d'Aveto & N. Casagli & 76 & Slovakia & Liptovska Mara & P. Wagner \\
\hline 34 & Italy & Monteforte Irpino & G. Urciuoli & 77 & Slovakia & Morovno Estate & P. Wagner \\
\hline 35 & Italy & Ponti & M. Lovisolo & 78 & Slovakia & Okolicne & P. Wagner \\
\hline 36 & Italy & Ruinon & M. Lovisolo & 79 & Slovakia & Slanec & P. Wagner \\
\hline 37 & Italy & Idro & M. Lovisolo & 80 & Slovakia & Velka Izra & P. Wagner \\
\hline 38 & Italy & Bagnaschino & M. Lovisolo & 81 & Slovakia & Velka Causa & P. Wagner \\
\hline 39 & Italy & Ancona & S. Cardellini & 82 & Slovakia & Vistuk & P. Wagner \\
\hline 40 & Italy & Chervaz & M. Broccolato, J. Blanc & 83 & Japan & Kuchisakamoto & G. Furuya \\
\hline 41 & Italy & Comba Citrin & M. Broccolato, J. Blanc & 84 & Japan & Aratosawa & S. Tosa \\
\hline 42 & Italy & Cherz & A. Passuto & 85 & Japan & Yui & S. Tosa \\
\hline 43 & Italy & Passo della Morte & A. Passuto & 86 & Japan & Takisaka & H. Marui \\
\hline
\end{tabular}

abundant ground-based geophysical methods of investigation at the reported landslides. Other frequently used methods were the reflection seismic surveying (17\% total relative occurrence), self-potential survey $(15 \%)$ and groundpenetrating radar $(15 \%)$. Geophysical logging $(85 \%$ reliability), resistivity surveys ( $82 \%)$ and the refraction seismic analysis $(80 \%)$ were considered as the most reliable groundbased geophysical methods. For the graphical presentation of the methods' review and for their type-specific relative occurrence at particular landslide types, see Fig. 7.

\subsection{Remote-sensing approaches for landslide investigation and monitoring}

The most frequently applied remote-sensing data and techniques for landslide investigation were aerial photographs (applied at $36 \%$ of the sites), radar interferometry (17\%) and lidar ALS (airborne laser scanners)(17\%) (see Fig. 8). Reliability of the remote-sensing methods was evaluated for both the structural investigation and for monitoring of movement. The most reliable remote-sensing methods were unequivocally evaluated to be lidar ALS (91\% reliability), then aerial photographs $(83 \%)$ and satellite optical very-high-resolution images $(76 \%$ reliability). Their application for particular landslide types, however, differed. For the graphical presentation and for the methods' review, see Fig. 8 .

\subsection{Monitoring parameters related to displacement and deformation}

The displacement and its derivatives - the velocity and the acceleration - were considered as the most relevant 


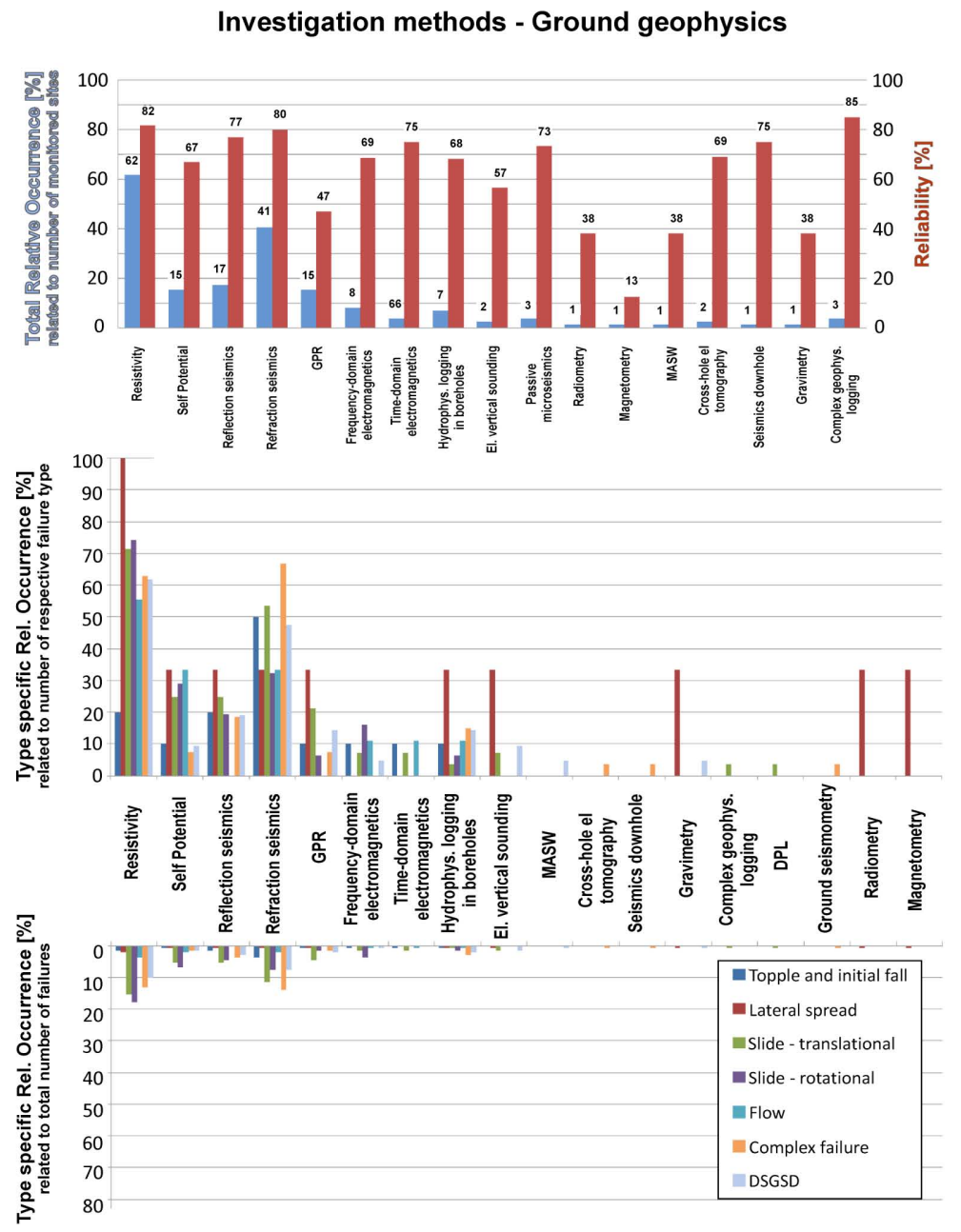

Fig. 7. Review of total relative occurrence, reliability and type-specific relative occurrence of the geophysical methods applied for the investigation of the monitored landslide sites.

monitoring parameters. The results for different groundbased sensors are presented in Fig. 9 displaying their EW (early warning) potential, total relative occurrence within all 86 monitoring sites, and type-specific relative occurrence. Classical and automated inclinometers, wire extensometers, dGPS, optical images and total stations are the most reliable sensors of displacement and deformation monitoring with the highest early warning potential.

\subsection{Hydro-meteorological monitoring parameters}

A total of 16 different hydro-meteorological monitoring parameters had been observed in the listed landslide sites; the precipitation amount, pore-water pressure and air temperature were the most abundant ones (Fig. 10). They were monitored at more than $55 \%$ of the test sites. Pore-water pressure and precipitation amount had the highest EW potential. The observation of particular parameters differed within different landslide types as documented by the type-specific relative occurrence (Fig. 10).

\subsection{Geophysical monitoring parameters}

The practical use of the geophysical parameters for monitoring is far from their routine application for landslide investigation; their relative abundance is generally below $20 \%$. Passive seismic/acoustic emissions, electromagnetic emission and DC resistivity were evaluated as the most reliable geophysical parameters for EW by the questioned experts (Fig. 11). Regarding their EW Potential, the electromagnetic emissions and DC resistivity reached relatively high values; however, all the geophysical parameters are randomly used and remain of a rather academic importance at the moment. 

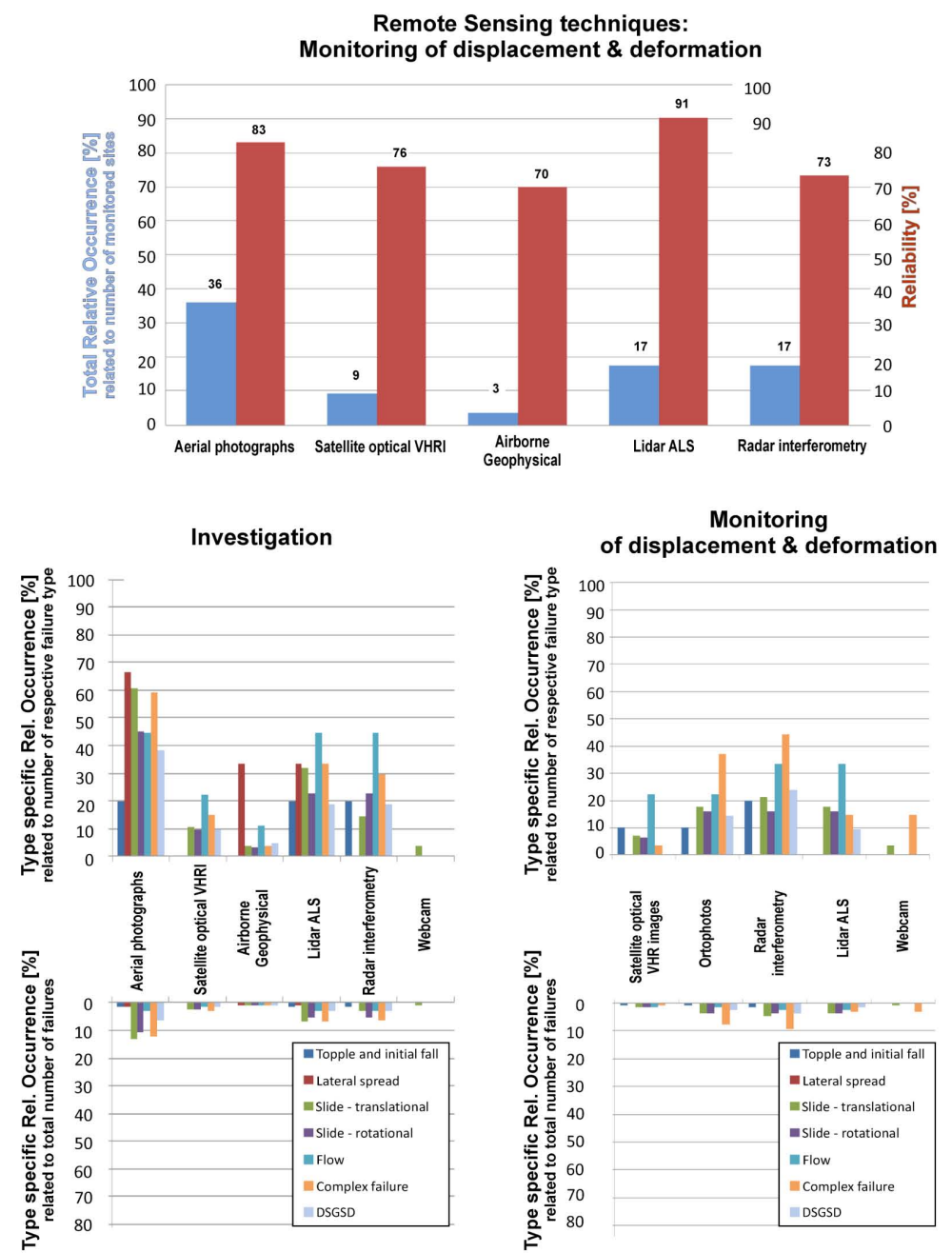

Fig. 8. Review of total relative occurrence, reliability and type-specific relative occurrence of the remote-sensing data applied for the investigation or monitoring of the case sites.

\subsection{Regional aspect of the applied monitoring techniques}

We observed some regional differences in the application of a particular investigation and monitoring technique within the landslide sites, especially when compared between countries of the former Western and Eastern Blocs. In general, strength testing, hydrochemical tracing, borehole testing, satellite optical VHR imagery, radar interferometry, airborne geophysics, lidar ALS and TLS (terrestrial lidar scanners), dGPS, automatic inclinometers, single lasers and superficial tiltmeters, ground-penetrating radar, hydrophysical logging in boreholes, monitoring of solar radiation, air humidity and soil/rock temperature, were distinctly more abundant approaches in the former "Western" countries in comparison to the "Eastern" ones. On the other hand, tape and wire extensometers, TM 71 optomechanical crack gauges, rod dilatometers, tools for monitoring surface residual stresses, monitoring of discharge, and ground-based geophysical surveys of DC resistivity, self potential, reflection seismic analysis, and frequency domain electromagnetics, were more abundant in the former "Eastern" countries. Other techniques were applied almost equally in both of the regions.

\section{Discussion}

The presented study reviewed and attempted to evaluate the recent general state of the slope-instability investigation and monitoring, the reliability of applied remote-sensing and ground-based methods, and the occurrence and applicability of monitoring techniques for early warning. The study was based on information collected from 86 monitored landslides in 14 European and Asian countries, which have been investigated with at least two independent methods and monitored for a longer time than $1 \mathrm{yr}$. Despite a certain degree of subjectivity of the answers, as the reliability and early warning 

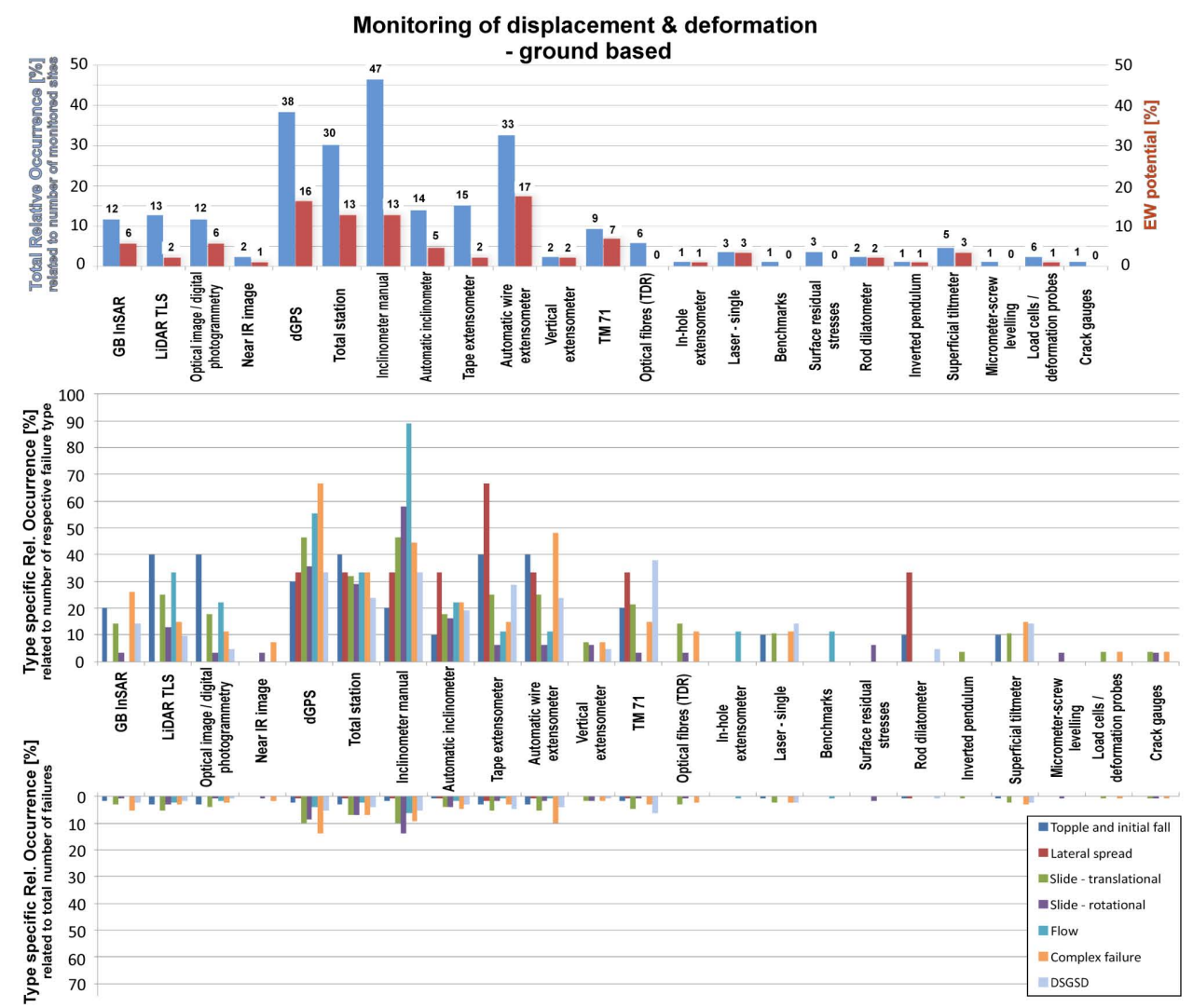

Fig. 9. Review of total relative occurrence, EW potential and type-specific relative occurrence of sensors for displacement and deformation monitoring from the 86 monitored landslide sites.

potential were assessed by the experts with different experience and profession, we believe that the study brought relatively complex and comprehensive information.

Slope instabilities comprising rotational and translational slides, topples, falls, ground flows and their complexes are being investigated and monitored by completely different methods. For example, some specific methods, applicable only for less abundant rockfalls, could appear in the evaluation less than methods applicable to a large spectra of mass movements or more abundant landslide types. Therefore any comparison of the relative occurrence of those methods is very difficult. The same restriction must be considered for monitoring methods and parameters and their early warning potential.

Based on the answered forms, Fig. 12 reviews and compares all of the methods regarding their reliability. Lidar ALS, complex geophysical logging in wells, aerial photographs, resistivity surveying, GB InSAR, and the refraction seismic analysis were considered unequivocally as the most reliable methods of the investigation of structure and character of landslides. Especially lidar ALS and TLS seem to be very challenging investigation methods for a broad spectra of slope-failure types as approved by recent literature (e.g.
Abellán et al., 2009; Jaboyedoff et al., 2012; Van Den Eeckhaut, 2007; etc.); this was confirmed also by our study despite the relatively seldom application of the technique at responded-to monitored landslides. The second most reliable method - the complex geophysical logging in wells - is probably ranked so high due to its ability to render information on the landslides' deep structure (McCann and Forster, 1990). In agreement with our observation, airborne photography is still a commonly used method for landslide investigation and mapping; the main advantage of aerial photography is, in addition to having the highest spatial resolution, the longest record of any remote-sensing data type (Stumpf et al., 2011). Electrical and seismic methods have been used in landslide practice for several decades and they are broadly applicable for investigating the landslides' internal structure (e.g. Bogoslovsky and Ogilvy, 1977; and Turner and Schuster, 1996). This was probably one of the reasons that they occurred in our responded-to sites so frequently.

Regarding the early warning potential of the monitoring methods and parameters, the precipitation amount, porewater pressure and displacement monitored by wire extensometers, dGPS and total stations, followed by air temperature, EM-emissions monitoring, and displacement monitored 


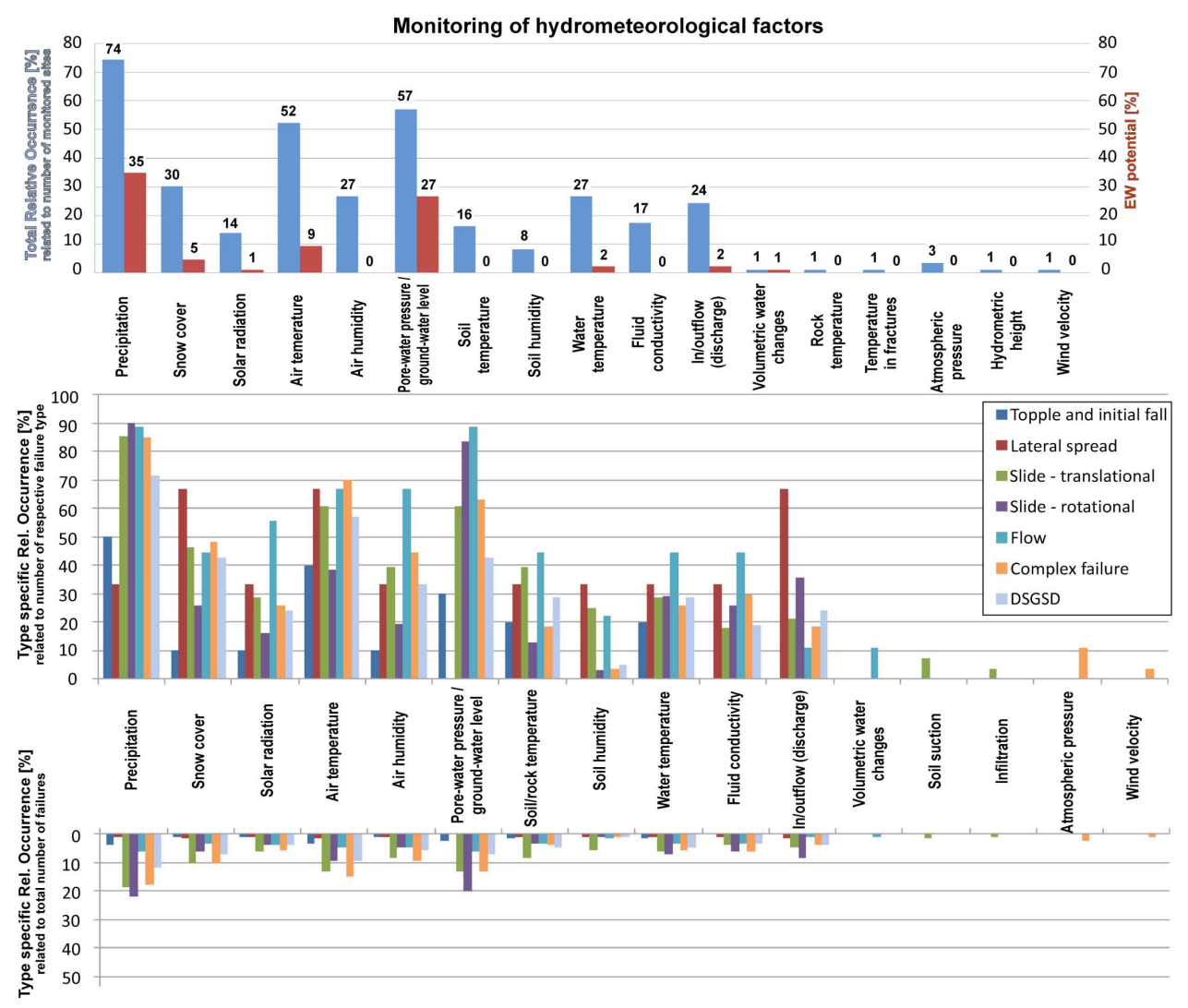

Fig. 10. Review of total relative occurrence, EW potential and type-specific relative occurrence of hydro-meteorological monitoring parameters from the 86 monitored landslide sites.

by the TM 71 crack gauge were considered the most promising parameters for early warning (Fig. 12). The precipitation amount is one of most common indirect triggering factors of landslides (Wieczorek, 1996) and it is reported in our study to be the most promising monitoring parameter for EW (Fig. 13). The warning could be based on landslide-triggering rainfall thresholds (Guzzetti et al., 2008), rainfall could be used as a dynamic variable along with the static variables of land surface factors in logistic regression approaches to landslide medelling, and the rainfall data could serve as an input for process-based hydrologic-geotechnical models (review by Apip et al., 2010); satellite real-time rainfall data are the substantial base for landslide EW systems at regional scales (e.g. Aleotti, 2004; Apip et al., 2010; Hong and Adler, 2007; and Strauch and Castellon, 2009). Real-time meteorological and geotechnical/hydrological monitoring is an essential part of any operational landslide warning system (Baum et al., 2005; Baum and Godt, 2010; Corominas et al., 2005; Keefer et al., 1987). In agreement with this statement, pore-water pressure, and displacement monitored by wire extensometers, dGPS and total stations were ranked very high also by our respondents. Air temperature is a frequently monitored parameter in the landslide monitoring networks as well as the seasonal temperature variations are able to induce, under the central European climate regime, irregular seasonal oscillations of volume changes of rock up to $2 \mathrm{~mm}$ that interfere with the detection of permanent displacements (Košt'ák, 2006). The high EW potential of this parameter, evaluated by the respondents, corresponds also to its role, e.g. in rockfall triggering. The EM-emissions (passive/pulse electromagnetic emissions - PEE or called natural pulsed electromagnetic field of earth - NPEMFE) are reported as a new promising monitoring parameter of slope failures (e.g. Aitmanov et al., 1997; Burdakova et al., 2005; Kharkhalis 1996; Lauterbach, 2005; and Wagner et al., 2002), and within our study was also ranked by the respondents relatively high. And finally, the TM 71 crack gauge was ranked so high probably thanks to its high accuracy, ability to measure the movement of particular pairs of blocks in 3-D including rotations and resistance in harsh field conditions (Košt'ák, 2006), recently also profiting from its extension for automated data reading and transfer (Klimeš et al., 2012). DC resistivity, GB InSAR, optical image, automatic inclinometer and other relatively less ranked but modern methods suffered probably from their random use. They could, similarly to other even 


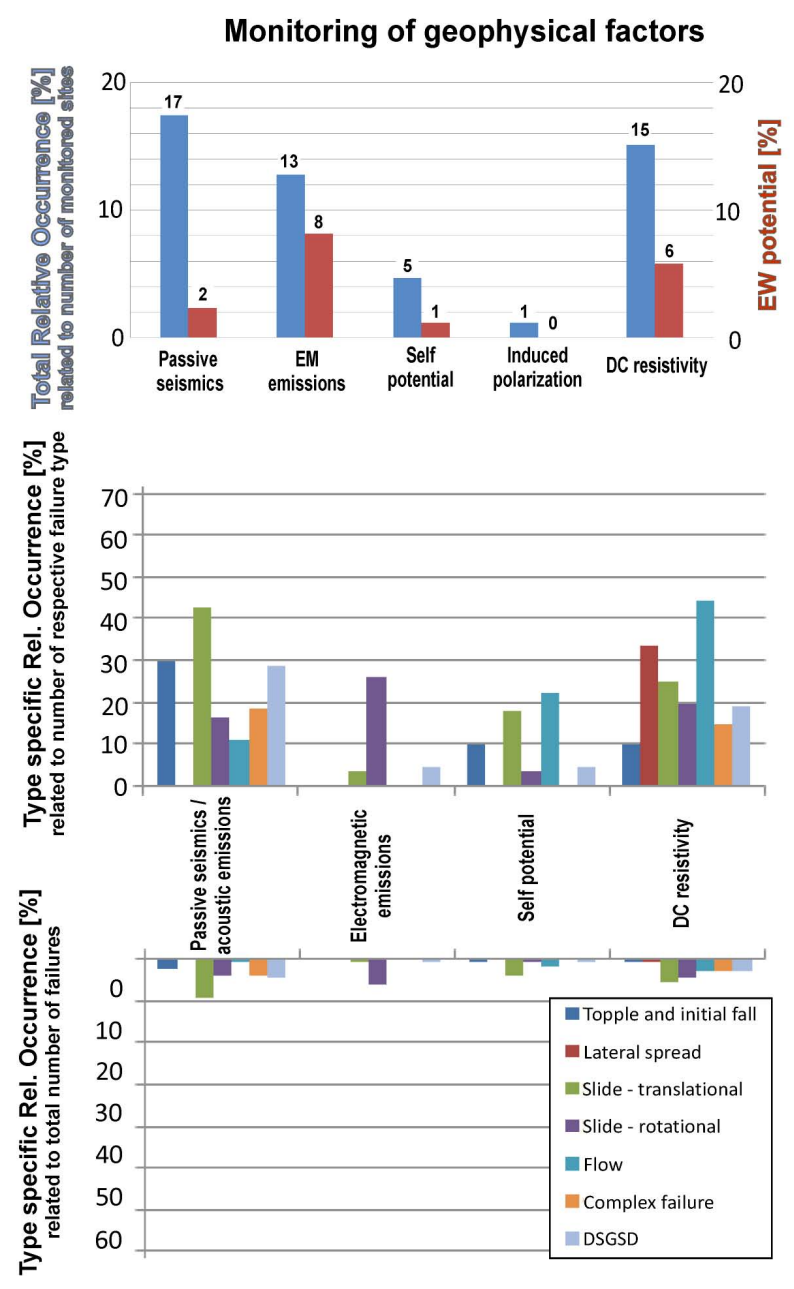

Fig. 11. Review of total relative occurrence, EW potential and typespecific relative occurrence of of geophysical monitoring parameters from the 86 monitored landslide sites.

lower ranked methods, have a high EW potential if they were used more commonly in practice and were more mature.

There could be many reasons for the regional differences that we observed in the application of particular investigation and monitoring techniques at the landslide sites, especially when compared between countries of the former Western and Eastern Blocs. We suspect that those regional differences occur especially due to traditional national approaches; also the main scientific focus, education, and experience of persons in charge could have played some role; e.g. in Slovakia, much more engineering-geological and geotechnical approaches prevailed over the remote-sensing data, in contrary to, e.g. Italy, where the remote-sensing data played a substantial role. That could also be related to land use and vegetation cover of the monitored landslides making the application of remote-sensing data in densely forested Slovakia difficult. The economic situation of respective countries is a noticeable factor as well, as the modern, but still relatively expensive methods like lidar or dGPS, have occurred more in the "Western" countries, in contrast to the traditional methods applied more in the "Eastern" countries.

\section{Conclusions}

The study reviewed and evaluated methods of landslide investigation and monitoring based on the information obtained from 86 real slope failures monitored in Europe and Asia.

From a total of 129 different monitored slope-failure types, the most abundant ones were rotational slides and translational active slides with recent movement rates of less than $10 \mathrm{~mm} \mathrm{month}^{-1}$, and deep-seated gravitational slope deformations. The particular landslide types, however, formed complex failures at about $31 \%$ of the monitored sites. The most frequently used mapping and testing surveys were the geological, engineering-geological and geomorphic mappings, core drilling, strength properties/deformability tests, clay mineralogy testing, and borehole testing. The most abundant ground-based geophysical methods of investigation were DC resistivity and refraction seismic analysis, reflection seismic analysis, self-potential survey and groundpenetrating radar; the complex geophysical logging in boreholes, resistivity survey and the refraction seismic analysis were the most reliable ones.

Among the most frequently applied remote-sensing data and techniques for landslide investigation were aerial photographs, radar interferometry and lidar ALS, and as the most reliable were unequivocally evaluated to be lidar ALS, aerial photographs and satellite optical very-high resolution images.

Classical and automated inclinometers, wire extensometers, dGPS, optical images and total stations were ranked as the most reliable sensors of displacement and deformation monitoring with the highest early warning potential. The precipitation amount, pore-water pressure and air temperature were the most abundant hydro-meteorological monitoring parameters listed in the landslide sites; pore-water pressure and precipitation amount had the highest EW potential.

Passive seismic/acoustic emissions, electromagnetic emissions and DC resistivity were evaluated as reliable geophysical monitoring parameters for EW. However, all the geophysical parameters were randomly used for monitoring and remain of rather academic importance to date. Regional differences in the application of different methods were observed. 


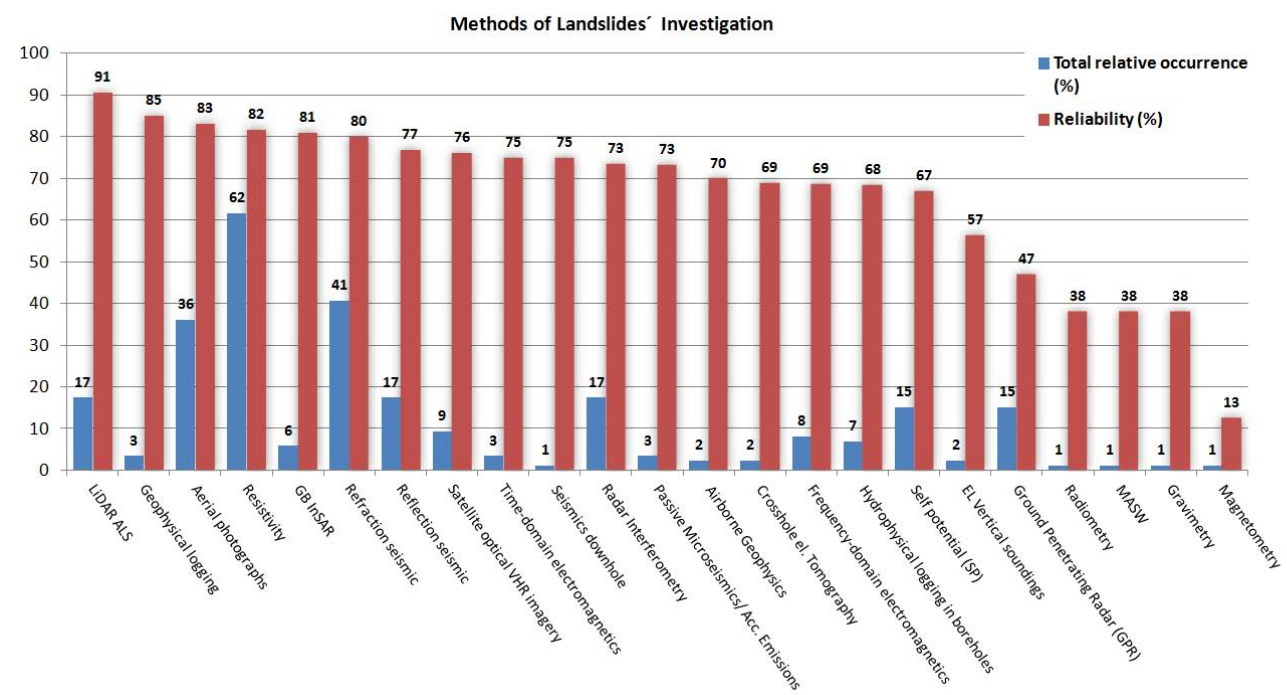

Fig. 12. Comparison of all of the evaluated methods of landslide investigation ordered by their reliability.

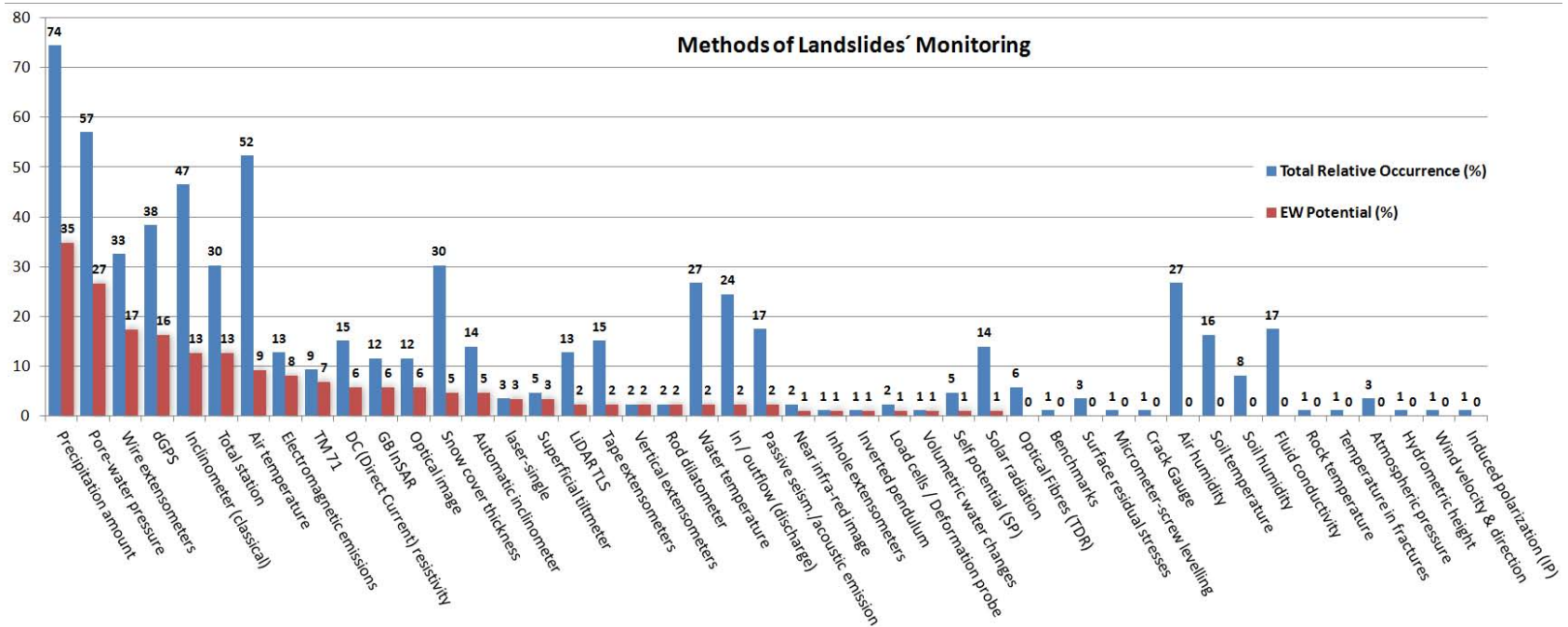

Fig. 13. Comparison of all of landslide monitoring methods included in the study ordered by their early-warning potential (red).

Acknowledgements. The authors would like to acknowledge everyone who helped through discussions to improve the questionnaire to make it as comprehensive and user-friendly as possible. Special thanks go to all the local national coordinators who helped to distribute the questionnaire effectively and to obtain as many answers as possible; and, of course all specialists and responsible persons who filled in the questionnaires must be thanked, i.e.: $\mathrm{M}$. Bíl, P. Bláha, J. Blanc, L.H. Blikra, M. Broccolato, S. Cardellini, M. Carman N. Casagli, V. Clouard, J. Corominas, C. Foster, G. Furuya, S. Garambois, W. Gasperl, V. Hanzl, F. Hartvich, A. Helmstetter, Ch. Ihrenberger, M.M. Ilyin, D. Jongmans, V. Kaufmann, J. Klimeš, S. Kumelj, M. Lovisolo, J.-F. Malet, H. Marui, S. Novosad, A. Passuto, L. Picarelli, J. Rybář, K. Sassa, S. Springman, I. Torgoev, S. Tosa, G. Truffelli, G. Urciuoli, Z. Vařilová, P. Wagner, and M. Wöhrer-Alge. S. Kauer is acknowledged for her help with distributing the questionnaire, J. Baroňová is acknowledged for her help with processing the responses, and $\mathrm{H}$. Vomlelová is acknowledged for revising the language. The present work was partially supported by the project SafeLand "Living with landslide risk in Europe: Assessment, effects of global change, and risk management strategies" (7th Framework Programme of the European Commission, Grant Agreement No. 226479). This support is gratefully acknowledged.

Edited by: F. Catani

Reviewed by: three anonymous referees

\section{References}

Abellán, A., Jaboyedoff, M., Oppikofer, T., and Vilaplana, J. M.: Detection of millimetric deformation using a terrestrial laser 
scanner: experiment and application to a rockfall event, Nat. Hazards Earth Syst. Sci., 9, 365-372, doi:10.5194/nhess-9-3652009, 2009.

Aitmanov, I. T., Torgoyev, I. A., Alioshin, and Yu, G.: Monitoring of Dangerous Geodynamical Processes in Highland Areas, edited by: Zhang, Z. et al., Proceedings of the 30th International Geological Congress, vol. 2\&3, 1-7, 1997.

Aleotti, P.: A warning system for rainfall-induced shallow failures, Eng. Geol., 73, 247-265, 2004.

Angeli, M.-G., Pasuto, A., and Silvano, S.: A critical review of landslide monitoring experiences, Eng. Geol., 55, 133-147, 2000.

Apip, Takara, K., Yamashiki, Y., Sassa, K., Ibrahim, A. B., and Fukuoka, H.: A distributed hydrological-geotechnical model using satellite-derived rainfall estimates for shallow landslide prediction system at a catchment scale, Landslides, 7, 237-258, 2010.

Baum, R. L. and Godt, J. W.: Early warning of rainfall-induced shallow landslides and debris flows in the USA, Landslides, 7, 259272, 2010.

Baum, R. L., Godt, J. W., Harp, E. L., McKenna, J. W., and McMullen, S. R.: Early warning of landslides for rail traffic between Seattle and Everett, Washington, USA, in: Landslide risk management, edited by: Hungr O., Fell R., Couture R., and Eberhardt E., Proceedings of the International Conference on Landslide Risk Management, Vancouver, Canada, 30 May-3 June 2005, Balkema, New York, 731-740, 2005.

Bogoslovsky, V. and Ogilvy, A.: Geophysical Methods for the Investigation of Landslides, Geophysics, 42, 562-571, 1977.

Burdakova, E. V., Glinskaya, N. V., and Palamarchuk, V. K.: Shortterm prediction of the landslides initiated activity in studies of the steep slopes, Geophys. Res. Abstr., 7, 09955, 2005.

Corominas, J., Moya, J., Ledesma, A., Lloret, A., and Gili, J. A.: Prediction of ground displacements and velocities from groundwater level changes at the Vallcebre landslide (East-ern Pyrenees, Spain), Landslides, 2, 83-96, 2005.

Cruden, D. M. and Varnes, D. J: Landslide types and processes, in: Landslides, Investigation and Mitigation, Special Report 247, Transportation Research Board, Washington, 36-75, 1996.

Guzzetti, F., Peruccacci, S., Rossi, M., and Stark, C. P.: The rainfall intensity-duration control of shallow landslides and debris flows: an update, Landslides, 5, 3-17, 2008.

Hong, Y. and Adler, R. F.: Towards an early-warning system for global landslides triggered by rainfall and earthquake, Int. J. Remote Sens., 28, 3713-3719, 2007.

Jaboyedoff, M., Oppikofer, T., Abellán, A., Derron, M.-H., Loye, A., Metzger, R., and Pedrazzini, A.: Use of LIDAR in landslide investigations: a review, Nat. Hazards, 61, 5-28, 2012.

Jongmans, D. and Garambois, S.: Geophysical investigation of landslides: a review, B. Soc. Geol. Fr., 178, 101-112, 2007.

Keefer, D. K., Wilson, R. C., Mark, R. K., Brabb, E. E., Brown, W. M., Ellen, S. D., Harp, E. L., Wieczorek, G. F., Alger, C. S., and Zatkin, R. S.: Real-time landslide warning during heavy rainfall, Science, 238, 921-925, 1987.

Kharkhalis, N. R.: Manifestation of natural electromagnetic pulse emission on landslide slopes, Int. J. Rock. Mech. Min., 33, 242, 1996.

Klimeš, J., Rowberry, M. D., Blahůt, J., Briestenský, M., Hartvich, F., Košt'ák, B., Rybáŕ, J., Stemberk, J., Štěpančíková, P.: The monitoring of slow-moving landslides and assessment of stabili- sation measures using an optical-mechanical crack gauge, Landslides, 9, 407-415, 2012.

Košt'ák, B.: Deformation effects in rock massifs and their long-term monitoring, Q. J. Eng. Geol. Hydroge., 39, 249-258, 2006.

Lauterbach, M.: Beurteilung der Eignung der NPEMFE-Methode (Natural Pulsed Electromagnetic Field of Earth) mit dem "Cereskop" in Rutschungen und in Lockerund Festgesteinen mit Spannungsänderungen im Mittel- und Hochgebirge, MS, Ph.D Thesis, 174 pp., published on-line at http://ubm.opus.hbz-nrw. de/volltexte/2007/1208/pdf/diss.pdf, 2005.

McCann, D. M. and Forster, A.: Reconnaissance geophysical methods in landslide investigations, Eng. Geol., 29, 59-78, 1990.

Michoud, C., Abellán, A., Derron, M.-H., and Jaboyedoff, M. (Eds.): SafeLand deliverable 4.1.: Review of Techniques for Landslide Detection, Fast Characterization, Rapid Mapping and Long-Term Monitoring, 2nd Edition, European Project SafeLand, Grant Agreement No. 226479, 401 pp., available at: http: //www.safeland-fp7.eu, 2012.

Michoud, C., Bazin, S., Blikra, L. H., Derron, M.-H., and Jaboyedoff, M.: Experiences from Site-Specific Landslide Early Warning Systems, NHESS, this volume, 2013.

Strauch, W. and Castellon, A.: Contribution to Early Warning on Landslides in Central America using precipitation estimates from meteorological satellite data in real time, Proceedings of the "International Lateinamerika-Kolloquium”, Göttingen, 7-9 April, 279-280, 2009.

Stumpf, A., Malet, J.-P., and Kerle, N. (Eds.): SafeLand deliverable 4.3 , Creation and updating of landslide inventory maps, landslide deformation maps and hazard maps as inputs for QRA using remotesensing technology, MS, Report of the European FP7 Project SafeLand, available on-line at http://www.safeland-fp7. eu, 2011.

Thiebes, B.: Landslide Analysis and Early Warning Systems: Local and Regional Case Study in the Schwabian Alb, Germany, Springer Theses, Recognizing Outstanding Ph.D. Research, Springer, Heidelberg, 257 pp., 2012.

Tofani, V., Segoni, S., Agostini, A., Catani, F., and Casagli, N.: Technical Note: Use of remote sensing for landslide studies in Europe, Nat. Hazards Earth Syst. Sci., 13, 299-309, doi:10.5194/nhess-13-299-2013, 2013.

Turner, K. and Schuster, R. (Eds.): Landslides: Investigation and Mitigation, Transportation Research Board-National Research Council, Special Report, 247, 673 pp., 1996.

Van Den Eeckhaut, M., Poesen, J., Verstraeten, G., Vanacker, V., Nyssen, J,, Moeyersons, J., Van Beek, L. P. H., and Vandekerckhove, L.: Use of LIDAR-derived images for mapping old landslides under Forest, Earth Surf. Proc. Land., 32, 754-769, 2007.

Wagner, P., Scherer, S., Jadroň, D., Mokrá, M., and Vybíral, V.: Analysis of landslide monitoring results, in: Landslides - Proceedings of the 1st European Conference on Landslides, edited by: Rybáŕ, J., Stemberk, J., and Wagner, P., Prague, Czech Republic, 24-26 June 2002, Swets \& Zeitlinger, Lisse, 471-476, 2002.

Wieczorek, G. F.: Landslide triggering mechanisms, in: Landslides: Investigation and Mitigation, edited by: Turner, K. and Shuster, R.: Transportation Research Board-National Research Council, Special Report, 247, 76-90, 1996. 